\title{
In Vitro Cytotoxicity and Molecular Effects Related to Silicon Nanoparticles Exposures
}

\author{
Elanur Aydın ${ }^{1,}{ }^{*}$, Hasan Türkez ${ }^{1}$, Fazıl Hacımüftüoğlu ${ }^{2}$ \\ ${ }^{1}$ Erzurum Technical University, Faculty of Science, Department of Molecular Biology and Genetics, Erzurum \\ ${ }^{2}$ Atatürk University, Faculty of Agriculture, Department of Soil Science and Plant Nutrition, Erzurum \\ e-mail:elanuraydinn@gmail.com \\ Geliş tarihi : 01.08.2016 Kabul tarihi : 02.03.2017
}

Keywords

Airway epithelial cell; Genotoxicity; In vitro gene expression;

Nanotoxicity; Silicon nanoparticles

\begin{abstract}
Silicon nanoparticles are widely used for various applications including environmental, biological, chemical and physical. And, to translate these nanomaterials to the clinic and industrial domains, their safety needs to be verified, particularly in terms of genotoxicity and cytotoxicity. Therefore, in this study, we aimed to investigate of cytotoxicity and changes in gene expression profiles influenced by commonly silicon (as silicon carbide, silicon dioxide, silicon nitride) nanoparticles in human alveolar epithelial (HPAEpiC) and pharynx (HPPC) cell lines in vitro since inhalation is an important pathway for exposure to these nanoparticles. HPAEpiC and HPPC cells were treated with silicon $(0-100 \mu \mathrm{g} / \mathrm{mL})$, nanoparticles for $72 \mathrm{~h}$, and then cytotoxicity was detected by, [3-(4,5-dimethyl-thiazol-2-yl) 2,5diphenyltetrazolium bromide] (MTT) and lactate dehydrogenase (LDH) release assays, while genotoxicity was also analyzed by CDNA array - RT-PCR assay. According to the results of MTT and LDH assays, all tested nanoparticles induced cytotoxicity on both HPAEpiC and HPPC cells in dose-dependent manner. Determining and analyzing the gene expression profiles of HPAEpiC and HPPC cells, silicon nanoparticles showed changes in genes related to apoptosis, DNA damage or repair and oxidative stress. This study of gene expression profiles affected by nanotoxicity provides critical information for the clinical and environmental applications of silicon nanoparticles.
\end{abstract}

\section{Silikon Nanopartikül Maruziyetine Bağlı Olarak Oluşan in Vitro Sitotoksik ve Moleküler Etkiler \\ Özet}

Silikon nanopartikülleri çevresel, biyolojik, kimyasal ve fiziksel amaçlarla çeşitli alanlarda yaygın olarak kullanılmaktadır. Bu nanopartiküllerin klinik ve endüstriyel alanlarda kullanılabilmesi için güvenilirlikleri özellikle genotoksisite ve sitotoksisite açısından doğrulanmalıdır. Bu yüzden mevcut çalışmada, yaygın olarak kullanılan silikon nanopartiküllerinin ( silikon karbid, silikon dioksit, silikon nitrit) insan alveolar epitel (HPAEpiC) ve farinks (HPPC) hücrelerindeki sitotoksisitesi ve gen ekspresyon profillerindeki değişimlerin araştırılması amaçlanmıştır. HPAEpiC ve HPPC hücreleri 72 saat boyunca silikon nanopartikülleriyle $(0-100 \mu \mathrm{g} / \mathrm{mL})$ muamele edildi. Nanopartiküllerin sitotoksisite değerlendirmeleri için 3-(4,5 dimetylthiazol -2-yl) - 2,5 diphenltetrazolium bromide (MTT) ve laktat dehidrogenaz salınım (LDH) yöntemleri kullanıııken; genotoksisite analizi için cDNA array - RT-PCR yöntemi kullanıldı. MTT ve LDH yöntemi sonuçlarına göre, uygulanan bütün test nanopartikülleri hem HPAEpiC hem de HPPC hücre hatlarında doza bağlı olarak sitotoksisiteyi indüklemiştir. HPAEpiC ve HPPC hücrelerinin ilgili genler açısından (apoptozis, DNA fasarı ve tamiri, oksidatif stres) gen ekspresyon profilleri incelendiğinde silikon naopartiküllerinin ekspresyonu değiştirdiği gözlenmiştir. Bu çalışmadan elde edilen nanotoksisiteye bağlı olarak oluşan gen ekspresyon profilleri, silikon nanopartiküllerin klinik ve çevresel uygulamalarda kullanılabilmesi için önemli bir kaynak oluşturmaktadır. 


\section{Introduction}

Nano-scale materials have at least one size in the range of $100 \mathrm{~nm}$ or less (The Royal Society and The Royal Academy of Engineering 2004). Nanoscale natural products can be produced by inherently consisting of processes such as volcanic events, fire, and erosion; as such, living things have been exposed to this particles. On the other hand, non-natural nanoparticles can enter the natural environment indeliberately via atmospheric diffusion, household waste, and farming and inadvertently release in the case of production/transportation (Zhang and Elliott 2006; Stampoulis et al. 2009). However, owing to singular their physical, mechanical and chemical properties, nanomaterials are commonly used in commercially available in personal care products, pharmaceuticals and foods (Yolanda 2016, Ong et al. 2016). The overwhelming growing production and use of nanomaterials result in an increasing number of workers and consumers exposed to nanomaterials via inhalation, dermal contact, or gastrointestinal tracts and other routes (Huang et al. 2009). Generally, nanomaterials are thought to have more serious adverse effects on organisms than micromaterials. Because, nanomaterials have smaller sizes and corresponding larger specific surface area than micromaterials (Kipen and Laskin 2005, Oberdorster et al. 2005, Nel et al. 2006). Many researchers and we have studied the different potential effects of nanomaterials with various compositions and properties on human and environmental health in vitro and in vivo settings (Sonmez et al. 2015, Leite-Silva et al. 2016, Turkez et al. 2016).

Nanostructures of silicon, including particles, dots, wires, rods and ribbons, have sparked much interest due to their unique electronic/mechanical properties and the improved performances, and make their potential application in many areas such as optoelectronic devices, solar cells and biological markers (Chantrenne and Lysenko 2005, Cavarroc et al. 2006, Zschech et al. 2007, Baca et al. 2007, Schmidt et al. 2009, Heintz et al. 2010). Among the different routes of nanoparticles exposure include inhalation, dermal, oral, and in the case of biomedical applications. Inhalation is the most important from these possible exposure routes (Amoabediny et al. 2009). The exposed of silicon dioxide $\left(\mathrm{SiO}_{2}\right)$ caused to pulmonary fibrosis in rats (Chen et al. 2004). In previous study, exposure of human bronchoalveolar carcinomaderived cells to $\mathrm{SiO}_{2}$ nanoparticles revealed doseand time-dependent cytotoxicity (Lin et al. 2006). Mechanistic studies suggest that the cytotoxicity is due to elevated oxidative stress, oxidative DNA damage and lipid peroxidation (Gurr et al. 2005, Gerloff et al. 2009, Asadpour et al. 2016).

In this study, we investigated silicon nanoparticles (as silicon carbide, silicon dioxide, silicon nitride)-mediated changes in cellular pathway-specific gene expression associated with DNA damage or repair (ATM, Rad23 and Rad50), apoptosis (Anxa5 and Fasl) and oxidative stress (Gpx2, Gs, Mt2, Cyp4a10) in human alveolar epithelial (HPAEpiC) and pharynx (HPPC) cell lines. Also, the relationships between cytotoxicity and gene expression of selected genes were determined.

The objectives of the present study were to understand the relationships between the following responses of HPAEpiC and HPPC to silicon nanoparticles: (1) cytotoxicity, and (2) genotoxicity (expression of selected genes).

\section{Material and Methods}

\section{Cell cultures and treatment with silicon nanoparticles}

HPAEpiC and HPPC cell lines (Science Cell, USA) was obtained from Sciencell Research Laboratories, Carlsbad, USA. Prior to the experiments, the cells were thawed and grown in tissue culture flasks as a monolayer in Dulbeccomodified Eagles-F12 medium (Sigma-Aldrich, USA) supplemented with $1 \%$ glutamine, $0.5 \%$ penicillin/streptomycin (PAN Biotech), and 10\% fetal bovine serum at $37^{\circ} \mathrm{C}$ in a humidified (95\%) incubator with $\mathrm{CO}_{2}(5 \%)$. The cultured cells were trypsinized with trypsin/EDTA for a maximum of 5 min and seeded with a subcultivation ratio of 1:31:8. HPAEpiC and HPPC cells were incubated with different concentrations $(0,5,10,20,40,80$ and $100 \mu \mathrm{g} / \mathrm{mL}$ ) of silicon NPs [silicon carbide (SiC; CAS No. 409-21-2), silicon dioxide $\left(\mathrm{SiO}_{2}\right.$; CAS No. 
7631-86-9), silicon nitride $\left(\mathrm{Si}_{3} \mathrm{~N}_{4}\right.$; CAS No. 1203389-5)](Sigma-Aldrich, USA) and incubated in a 96well microtitre plates in triplicate at $37{ }^{\circ} \mathrm{C}, 5 \%$ $\mathrm{CO}_{2}$ for $72 \mathrm{~h}$.

\subsection{Cytotoxicity testing}

\section{MTT assay}

Cytotoxicity was assessed by measuring the formation of a formazan from 3-(4,5dimethylthiazol-2-yl)-2,5-diphenyl tetrazolium bromide (MTT) spectrophotometrically test. HPAEpiC and HPPC cells were incubated with 0.7 $\mathrm{mg} / \mathrm{ml} \mathrm{MTT}$ for $30 \mathrm{~min}$ at $37{ }^{\circ} \mathrm{C}$ for $72 \mathrm{~h}$ at the end of the experiment. After washing with PBS the blue formazan was extracted from cells with isopropanol/formic acid (95:5). Cytotoxicity was photometrically determined at $560 \mathrm{~nm}$ using a Microquant reader.

\section{Lactate dehydrogenase assay}

Lactate dehydrogenase (LDH) activity was measured in the culture medium after $72 \mathrm{~h}$ as an index of cytotoxicity, employing an LDH kit (Bayer Diagnostics ${ }^{\circledR}$, France) adapted to the auto analyzer (ADVIA 1650, USA). Enzyme activity was expressed as the extra-cellular LDH activity percentage of the total activity in the wells.

\subsection{Gene expression alteration by silicon nanoparticles}

CDNA array-real-time RT-PCR assay was performed and scored with slight modifications according to Melo et al. (2010). Gene expression was determined by cDNA array-RT-PCR assay. HPAEpiC and HPPC were lysed using $500 \mu \mathrm{L}$ Trizol reagent. After $10 \mathrm{~min}$ incubation at room temperature, $200 \mu \mathrm{L}$ of chloroform, which is chilled in $-20^{\circ} \mathrm{C}$, was added to the tubes and incubated $5 \mathrm{~min}$ at room temperature. At the end of the incubation period, tubes was centrifuged at $12,000 \mathrm{~g}$ for $15 \mathrm{~min}$ in $+4^{\circ} \mathrm{C}$. Including RNA the top aqueous phase was removed and transferred to a fresh tube. The RNA was pelleted by centrifugation at $12,000 \mathrm{~g}\left(+4^{\circ} \mathrm{C}\right)$ for $15 \mathrm{~min}$ and precipitated with ice-cold ethanol. The RNA pellet was air-dried and resuspended in $200 \mu \mathrm{L}$ RNasefree water, treated with $200 \mu \mathrm{L}$ DNase I, then immediately was maintained at $-70{ }^{\circ} \mathrm{C}$. RNA amount was measured using UV spectrophotometry at $260 \mathrm{~nm}$. The purity and structural integrity of the RNA samples was evaluated by UV absorbance of the $260 / 280 \mathrm{~nm}$ ratio and visually checked on a $1 \%$ agarose gel stained with ethidium bromide $(5 \mathrm{mg} / \mathrm{mL}$ ). CDNA probes were synthesized using the High-Capacity cDNA Reverse Transcription Kit including the Moloney murine leukemia virus reverse transcriptase. $10 \mu \mathrm{L}$ of $2 x$ Real Time master mix was added into each well of a 96-well reaction plate. Then, into the same wells was added $10 \mu \mathrm{L}$ of RNA sample, and was pipetted up and down two times to mix. Plates was centrifuged to spin down the contents and to eliminate any air bubbles for a very short time. Plates were placed to the thermal cycler. Thermal cycling conditions were $10 \mathrm{~min} 25^{\circ} \mathrm{C}$, followed at $37^{\circ} \mathrm{C}$ for $120 \mathrm{~min}$, and finally $85^{\circ} \mathrm{C}$ for 5 .

\section{RT-PCR Assay}

A simple RT-PCR method of using the specific primers was applied to detect the differential mRNA expression of HPAEpiC and HPPC cells. The primer sequences were retrieved benefiting data from the public database. While PCR analysis was performed, glyceraldehyde-3-phosphate dehydrogenase (GAPDH) gene sequence was used as housekeeping control. PCR amplification products were analyzed on $1.5 \%$ agarose gels in the presence of ethidium bromide $(0.5 \mu \mathrm{g} / \mathrm{mL})$. Then, it was electrophoresed for $1 \mathrm{~h}$ at $100 \mathrm{~V}$, and was photographed. Finally, the densities of the bands on the agarose gels were measured using the DNA imaging system. Data were measured as densitometry units according to the density of the GAPDH bands.

\section{Statistical analysis}

Statistical analysis was performed using SPSS Software (version 18.0, SPSS, Chicago, Illinois, USA). For statistical analysis of the obtained data, 
Duncan's test was used. Statistical decisions were made with a significance level of 0.05 .

\section{Results}

Similar results were observed in both cell lines treated with all kinds of silicon nanoparticles. According to determination of cell viability using MTT assay, applied all silicon nanoparticles showed a dose- and time-dependent cytotoxicity in HPAEpiC and HPPC cells (Table 1.). Silicon nanoparticles exposure exhibited a significant cytotoxicity at all tested concentrations in both cell lines in $72 \mathrm{~h}$. The IC20 values of MTT, which show the limiting value of toxicity, calculated to be closely $10 \mu \mathrm{g} / \mathrm{ml}$ for all silicon nanoparticles in both cell lines.

Table 1. Cell viability in HPAEpiC and HPPC cell cultures maintained $72 \mathrm{~h}$ in the presence of silicon NPs. (Control: HPAEpiC and HPPC cells without silicon NPs. Values inside the rectangle are statistically different from the corresponding control,* symbol presents significant differences at the $p<0.05$ level from the control group.)

\begin{tabular}{|c|c|c|c|c|c|c|}
\hline & \multicolumn{2}{|c|}{$\underline{\mathrm{SiC}}$} & \multicolumn{2}{|c|}{$\underline{\mathrm{SiO}}_{2}$} & \multicolumn{2}{|c|}{$\underline{\mathbf{S i}}_{3} \underline{\mathbf{N}}_{4}$} \\
\hline & HPAEpiC & HPPC & HPAEpiC & HPPC & HPAEpiC & HPPC \\
\hline \multicolumn{7}{|l|}{ Concentrations } \\
\hline $0 \mu \mathrm{g} / \mathrm{mL}$ & $57,95 \pm 1,09$ & $60,36 \pm 1,06$ & $57,95 \pm 1,09$ & $60,36 \pm 1,06$ & $57,95 \pm 1,09$ & $60,36 \pm 1,06$ \\
\hline $5 \mu \mathrm{g} / \mathrm{mL}$ & $48,76 \pm 1,1^{*}$ & $53,14 \pm 1,06^{*}$ & $50,64 \pm 1,08^{*}$ & $55,39 \pm 1,08^{*}$ & $52,65 \pm 1,1^{*}$ & $55,29 \pm 1,08^{*}$ \\
\hline $10 \mu \mathrm{g} / \mathrm{mL}$ & $45,39 \pm 1,08^{*}$ & $48,36 \pm 1,07^{*}$ & $46,95 \pm 1,09 *$ & $50,72 \pm 1,09 *$ & $47,59 \pm 1,1^{*}$ & $51,36 \pm 1,07^{*}$ \\
\hline $20 \mu \mathrm{g} / \mathrm{mL}$ & $43,17 \pm 1,07^{*}$ & $44,17 \pm 1,1^{*}$ & $42,37 \pm 1,08 *$ & $46,81 \pm 1,08 *$ & $42,59 \pm 1,07^{*}$ & $46,11 \pm 1,09 *$ \\
\hline $40 \mu \mathrm{g} / \mathrm{mL}$ & $38,67 \pm 1,07^{*}$ & $39,41 \pm 1,1^{*}$ & $38,59 \pm 1,08^{*}$ & $41,29 \pm 1,07^{*}$ & $38,41 \pm 1,07^{*}$ & $41,38 \pm 1,08^{*}$ \\
\hline $80 \mu \mathrm{g} / \mathrm{mL}$ & $31,13 \pm 1,1^{*}$ & $34,07 \pm 1,08^{*}$ & $33,39 \pm 1,07 *$ & $37,45 \pm 1,07 *$ & $35,43 \pm 1,09 *$ & $37,48 \pm 1,08^{*}$ \\
\hline $100 \mu \mathrm{g} / \mathrm{mL}$ & $25,19 \pm 1,09 *$ & $30,25 \pm 1,08^{*}$ & $30,43 \pm 1,09 *$ & $33,48 \pm 1,1^{*}$ & $31,49 \pm 1,08 *$ & $32,34 \pm 1,09 *$ \\
\hline
\end{tabular}

As shown in Table 2, LDH leakage in HPAEpiC and HPPC cell lines increased in a time- and dosesdependent manner. A statistically significant increases in LDH concentration was observed at

all tested concentrations of silicon nanoparticles in both cell lines in $72 \mathrm{~h}$. Achieved results from LDH assay was in accordance with the cell viability results.

Table 2. LDH activities on HPAEpiC and HPPC cells treated with different concentrations of silicon NPs for $72 \mathrm{~h}$. (Control: HPAEpiC and HPPC cells without silicon NPs. Values inside the rectangle are statistically different from the corresponding control,* symbol presents significant differences at the $p<0.05$ level from the control group.)

\begin{tabular}{|c|c|c|c|c|c|c|}
\hline \multirow[b]{2}{*}{ Concentrations } & \multicolumn{2}{|c|}{$\underline{\mathrm{SiC}}$} & \multicolumn{2}{|c|}{$\mathrm{SiO}_{2}$} & \multicolumn{2}{|c|}{$\underline{S i}_{3} \underline{N}_{4}$} \\
\hline & HPAEpiC & HPPC & HPAEpiC & HPPC & HPAEpiC & HPPC \\
\hline $0 \mu \mathrm{g} / \mathrm{mL}$ & $67,23 \pm 0,8$ & $71,62 \pm 0,9$ & $67,23 \pm 0,8$ & $71,62 \pm 0,9$ & $67,23 \pm 0,8$ & $71,62 \pm 0,9$ \\
\hline $5 \mu \mathrm{g} / \mathrm{mL}$ & $75,49 \pm 0,7^{*}$ & $83,49 \pm 0,6 *$ & $78,39 \pm 0,9 *$ & $83,49 \pm 0,8^{*}$ & $74,59 \pm 0,9 *$ & $89,34 \pm 0,8^{*}$ \\
\hline $10 \mu \mathrm{g} / \mathrm{mL}$ & $97,92 \pm 0,8^{*}$ & $101,27 \pm 0,9 *$ & $94,95 \pm 0,9 *$ & $104,59 \pm 0,8^{*}$ & $87,30 \pm 0,6^{*}$ & $109,45 \pm 0,8^{*}$ \\
\hline $20 \mu \mathrm{g} / \mathrm{mL}$ & $117,85 \pm 0,9 *$ & $126,62 \pm 0,8^{*}$ & $107,31 \pm 0,8^{*}$ & $129,48 \pm 0,9 *$ & $98,43 \pm 0,7^{*}$ & $127,38 \pm 0,8^{*}$ \\
\hline $40 \mu \mathrm{g} / \mathrm{mL}$ & $139,97 \pm 0,9 *$ & $150,36 \pm 0,7^{*}$ & $121,34 \pm 0,6^{*}$ & $153,44 \pm 0,9 *$ & $123,54 \pm 0,6 *$ & $156,48 \pm 0,7^{*}$ \\
\hline $80 \mu \mathrm{g} / \mathrm{mL}$ & $179,12 \pm 0,8^{*}$ & $192,97 \pm 0,7^{*}$ & $149,47 \pm 0,6^{*}$ & $172,39 \pm 0,7^{*}$ & $155,43 \pm 0,7^{*}$ & $182,39 \pm 0,9 *$ \\
\hline $100 \mu \mathrm{g} / \mathrm{mL}$ & $195,62 \pm 0,7^{*}$ & $210,74 \pm 0,6^{*}$ & $173,26 \pm 0,7^{*}$ & $189,26 \pm 0,8^{*}$ & $183,49 \pm 0,9 *$ & $195,33 \pm 0,7^{*}$ \\
\hline
\end{tabular}

We analyzed, using RT-PCR, the expression changes of 9 selected genes associated with different metabolic pathways in HPAEpiC and HPPC cell lines. The selected molecular markers were annexin A5 (Anxa 5) and Fas ligand (FasL), apoptosis markers; ataxia-telangiectasia mutated (ATM), RAD 23 and RAD50, DNA damage markers; cytochrome P450, family 4, subfamily a, polypeptide 10 (Cyp4a10), glutathione peroxidase (GPX2), glutathione reductase (GSR) and melatonin receptor $1 \mathrm{~b}$ (MT2), oxidative stress markers.
Statistical analysis of silicon NPs were shown in Figures 1-3. In $10 \mu \mathrm{g} / \mathrm{ml} \mathrm{SiC}, \mathrm{SiO}_{2}$ and $\mathrm{Si}_{3} \mathrm{~N}_{4}$ nanoparticles-exposed both cells, Anxa, FasL, ATM, RAD23, RAD50, Cyp4a10, GPX2, GSR and MT2 genes were clearly induced by silicon nanoparticles exposure. In $10 \mu \mathrm{g} / \mathrm{ml} \mathrm{SiC}, \mathrm{SiO}_{2}$ and $\mathrm{Si}_{3} \mathrm{~N}_{4}$ nanoparticles increased the expression levels of all selected genes in both cell lines. 


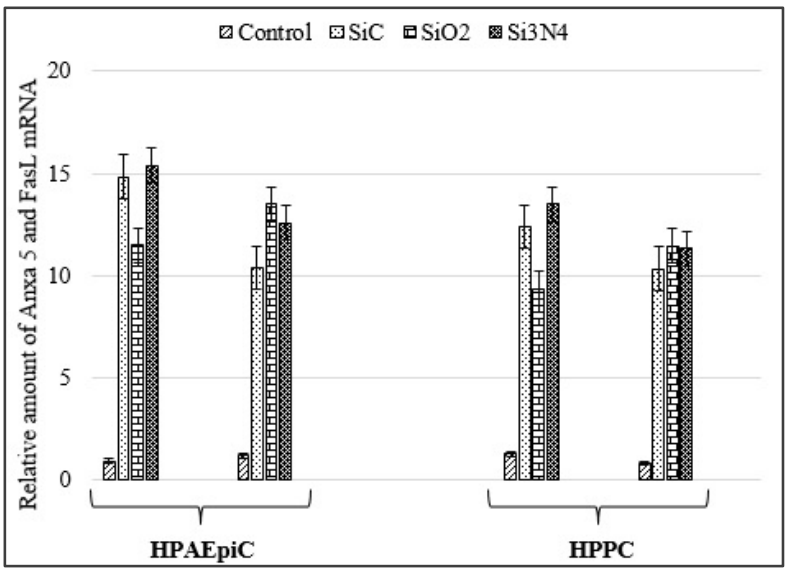

Figure 1. mRNA expression of apoptosis markers in silicon nanoparticles-exposed HPAEpiC and HPPC cells.

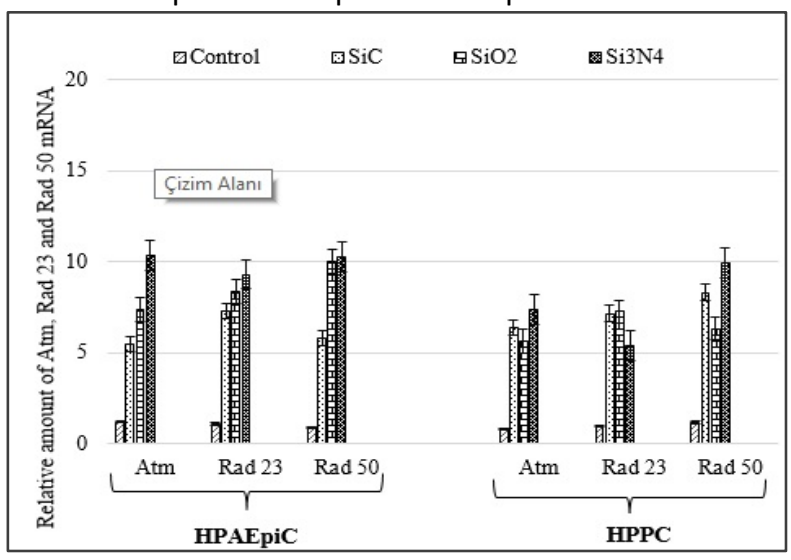

Figure 2. mRNA expression of DNA damage markers in silicon nanoparticles-exposed HPAEpiC and HPPC cells.

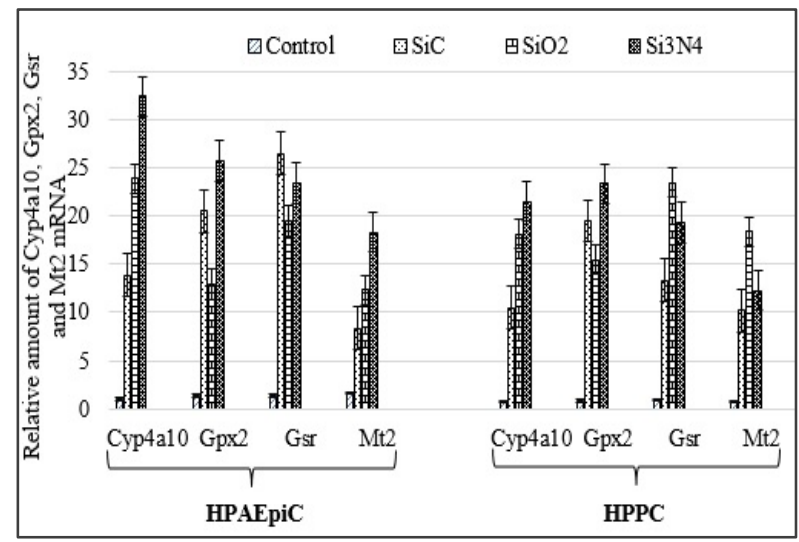

Figure 3. mRNA expression of oxidative stress markers in silicon nanoparticles-exposed HPAEpiC and HPPC cells.

\section{Discussion and Conclusion}

So far, although nanotechnological products and nanoparticles were used in many areas has been mostly ignored the potential effects in environment and human health. Especially nanoparticles, therefore smaller than $100 \mathrm{~nm}$ and specific features of their size can be easily integrated into biological systems. Thanks to these features, nanoparticles was used in many fields such as biomedical and medical field, intelligent drug delivery, imaging, biosensors, nanomachines (biorobot), the nucleic acid analysis, nanofabrication of DNA chip for bioinformatics and genomic applications, stem cell-based organ engineering applications, implant materials, artificial tissue and nanosurgical as well as they can cause irreversible damage in cells and tissues (Gök 2007, Kocaefe 2007, Tomalia et al. 2007, Portakal 2008, Syed et al. 2013, Atlı-Şekeroğlu 2013). Recently, various studies were identified the biological effects on tissues and organs of nanoparticles. But, it is necessary to investigate the potential toxicological effects in vivo and in vitro model systems (Ziady et al. 2003, Chen et al. 2006, Fischer and Chan 2007, Hwang et al. 2011). Thus, in the present study was focused on the nanotoxicity in order to understand of potential toxicity of nanoparticles in the genetic and cellular levels.

In this study, while MTT assay were used to determine the viability after exposure silicon nanoparticles, LDH assay was used to determine cytotoxicity in HPAEpiC and HPPC cells. The MTT assay was commonly used to define as quantitation of living cells still mitochondrially active in cultures (Brown et al. 1994). Also, LDH released into the medium provides an index of cell death and membrane permeability to LDH and an increase in LDH activity in the medium occurs as a result of cell membrane disintegration and enzyme leakage (Yokogawa et al. 2004). Applied all methods are often preferred in cytotoxicity studies. We demonstrated that all tested silicon nanoparticles have cytotoxic effect depending on dose- and time in HPAEpiC and HPPC cells. In previous study was investigated the cytotoxic effect of silicon dioxide $\left(\mathrm{SiO}_{(2)}\right) \mathrm{NPs}$ in human epidermal keratinocyte (HaCaT) cells using Cell Counting Kit-8 (CCK-8) assay. According to study results, $\mathrm{HaCaT}$ cells lines exposed to 
$\mathrm{SiO}_{(2)} \mathrm{NPs}$ showed cytotoxicity in a concentrationdependent and time-dependent manner (Gong et al. 2012). In a research conducted on murine macrophages (RAW 264.7), Choi et al. (2009) found that silicon NPs increased the cytotoxicity. Again, the results also support the observations of Yang et al. (2010), who have showed that exposure of $\mathrm{HaCaT}$ cells to $15-\mathrm{nm}$ and $30-\mathrm{nm} \mathrm{SiO}_{2}$ particles resulted in significantly decreased cell viability in a dose-dependent manner.

The RT-PCR was used for the studies of gene expression. The working with high sensitivity RTPCR assay is a measurement method that reliable, fast and requiring a small amount of sample (Ünlü and Sağlar 2012). The expression of genes associated with the processes DNA damage or repair, apoptosis and oxidative stress increased in different rates compared to control all concentrations of $\mathrm{SiC}, \mathrm{SiO}_{2}$ and $\mathrm{Si}_{3} \mathrm{~N}_{4} \mathrm{NPs}$ in both cells. To my knowledge, there are no studies in the literature. Therefore, we discussed on different nanoparticles to this section. In a previous study Park et al. (2008) reported that exposure of BEAS-2B cells to titanium dioxide NPs $(5,10,20$ and $40 \mu \mathrm{g} / \mathrm{ml})$ induced and increased

\section{References}

Amoabediny, Gh., Naderi, A., Malakootikhah, J., Koohi, MK., Mortazavi, S.A., Naderi, M. and Rashedi, H., 2009. Guidelines for safe handling, use and disposal of nanoparticles. Journal of Physics: Conference Series, 170, 012037.

Asadpour, E., Sadeghnia, H.R., Ghorbani, A., Sedaghat, M. and Boroushaki, M.T., 2016. Oxidative stressmediated cytotoxicity of zirconia nanoparticles on PC12 and N2a cells. Journal of Nanoparticle Research, 18, 14, (in press) DOI 10.1007/s11051-015-3316-7.

Baca, A.J ., Meitl, M.A ., Ko, H.C., Mack, S., Kim, H.S., Dong, J.Y., Ferreira, P.M. and Rogers, J.A., 2007. Printable single-crystal silicon micro/nanoscale ribbons, platelets and bars generated from bulk wafers. Advanced Functional Materials, 17, 30513062.

Brown, D.R., Herms, J. and Kretzschmar, H.A., 1994. Mouse cortical cells lacking cellular PrP survive in culture with a neurotoxic PrP fragment. Neuroreport, 5, 2057-2060.

Cavarroc, M., Mikikian, M., Perrier, G. and Boufendi, L., 2006. Single-crystal silicon nanoparticles: An the expression of the oxidative stress-related genes (including heme oxygenase-1, thioredoxin reductase, glutathione-S-transferase, catalase and hypoxia inducible gene). Okuda-Shimazaki et al. (2010) found, using quantitative RT-PCR, that titanium dioxide nanoparticle induce inflammation-related genes, including heat shock protein (HSP) and IL-6 in human acute monocytic leukemia cells (THP-1) and human bronchial epithelial cells ( $\mathrm{NCl}-\mathrm{H} 292$ ).

In the present study, the cytotoxicity and genotoxicity potentials of 3 diverse silicon nanoparticles in HPAEpiC and HPPC cells was evaluated by using MTT, LDH and RT-PCR methods, respectively. The obtained findings exhibited that all silicon NPs have cytotoxic effect as dose- and time-dependent and each nanoparticle increased the expressions of different genes which involved in metabolic processes in cells. As a result, if silicon nanoparticles use in the diagnosis and treatment of diseases such as cancer, they can have toxic effects on patients. Therefore, the safety standards at genetic and cellular levels of NPs must have been well identified.

instability to check their synthesis. Applied Physics Letters, 89, 013107

Chantrenne, P. and Lysenko, V., 2005. Thermal conductivity of interconnected silicon nanoparticles: Application to porous silicon nanostructures. Physical Review B, 72, 035318.

Chen, Y., Chen, J., Dong, J. and Jin, Y., 2004. Comparing study of the effect of nanosized silicon dioxide and microsized silicon dioxide on fibrogenesis in rats. Toxicology Industrial Health, 20, 21-27.

Chen, Z., Meng, H., Xing, G., Chen, C., Zhao, Y., Jia, G., Wang, T., Yuan, H., Ye, C., Zhao, F., Chai, Z., Zhu, C., Fang, X., Ma, B. and Wan, L., 2006. Acute toxicological effects of copper nanoparticles in vivo. Toxicology Letters, 163, 109-120.

Choi, J., Zhang, Q., Reipa, V., Wang, N.S., Stratmeyer, M.E., Hitchins, V.M. and Goering, P.L., 2009. Comparison of cytotoxic and inflammatory responses of photoluminescent silicon nanoparticles with silicon micron-sized particles in RAW 264.7 macrophages. Journal of Applied Toxicology, 29, 52-60.

Fischer, H.C. and Chan, W.C., 2007. Nanotoxicity: the growing need for in vivo study. Current Opinion in Biotechnology, 18, 565-571. 
Gerloff, K., Albrecht, C., Boots, A.W., Förster, I. and Schins, R.P.F., 2009. Cytotoxicity and oxidative DNA damage by nanoparticles in human intestinal Caco-2 cells. Nanotoxicology, 3, 355-364.

Gök, H., 2007. Nanotechnology: future directions from physiatrists' perspective. The Turkish Journal of Physical Medicine and Rehabilitation, 53, 13-17.

Gong, C., Tao, G., Yang, L., Liu, J., He, H. and Zhuang, Z., 2012. The role of reactive oxygen species in silicon dioxide nanoparticle-induced cytotoxicity and DNA damage in HaCaT cells. Molecular Biology Reports, 39, 4915-4925.

Gurr, J.R., Wang, A.S., Chen, C.H. and Jan, K.Y., 2005. Ultrafine titanium dioxide particles in the absence of photoactivation can induce oxidative damage to human bronchial epithelial cells. Toxicology, 213, 6673.

Heintz, A.S., Fink, M.J. and Mitchell, B.S., 2010. Silicon nanoparticles with chemically tailored S surfaces. Applied Organometallic Chemistry 24, 236-240.

Huang, C.C., Aronstam, R.S., Chen, D.R. and Huang, Y.W., 2010. Oxidative stress, calcium homeostasis, and altered gene expression in human lung epithelial cells exposed to $\mathrm{ZnO}$ nanoparticles. Toxicology In Vitro, 24, 45-55.

Hwang, D.W., Lee, D.S. and Kim, S., 2012. Gene expression profiles for genotoxic effects of silica-free and silica-coated cobalt ferrite nanoparticles. Journal of Nuclear Medicine, 53, 106-112.

Kipen, H.M. and Laskin, D.L., 2005. Smaller is not always better: nanotechnology yields nanotoxicology. American Journal of Physiology - Lung Cellular and Molecular Physiology, 289, 696-697.

Kocaefe, Ç., 2007. Nanotıp: Yaşam bilimlerinde nanoteknoloji uygulamaları. Hacettepe University Acta Medica, 38, 33-38.

Leite-Silva, V.R., Liu, D.C., Sanchez, W.Y., Studier, H., Mohammed, Y.H., Holmes, A., Becker, W., Grice, J.E., Benson, H.A. and Roberts, M.S., 2016. Effect of flexing and massage on in vivo human skin penetration and toxicity of zinc oxide nanoparticles. Nanomedicine (Londra), 11, 1193-1205.

Lin, W., Huang, Y.W., Zhou, X.D. and Ma, Y., 2006. In vitro toxicity of silica nanoparticles in human lung cancer cells. Toxicology and Applied Pharmacology, 217, 252-259.

Melo, E.S., Goloubkova, T., Barbeiro, D.F., Gorjão, R., Vasconcelos, D., Szabo, C., Curi, R., de Lima Salgado, T.M., Velasco, I.T. and Soriano, F.G., 2010. Endotoxin tolerance: selective alterations in gene expression and protection against lymphocyte death. Immunobiology, 215, 435-442.
Nel, A., Xia, T., Mädler, L. and Li, N., 2006. Toxic potential of materials at the nanolevel. Science, 311, 622-627.

Oberdorster, G., Oberdorster, E. and Oberdorster, J., 2005. Nanotoxicology: An emerging discipline evolving from studies of ultrafine particles. Environmental Health Perspectives, 113, 823-839.

Okuda-Shimazaki, J., Takaku, S., Kanehira, K., Sonezaki, S. and Taniguchi, A., 2010. Effects of titanium dioxide nanoparticle aggregate size on gene expression. International Journal of Molecular Sciences, 11, 23832392.

Ong, C., Lee, Q.Y., Cai, Y., Liu, X., Ding, J., Yung, L.Y., Bay, B.H. and Baeg, G.H., 2016. Silver nanoparticles disrupt germline stem cell maintenance in the Drosophila testis. Scientific Reports, 6, 20632.

Park, E.J., Yi, J., Chung, K.H., Ryu, D.Y., Choi, J. and Park, K., 2008. Oxidative stress and apoptosis induced by titanium dioxide nanoparticles in cultured BEAS-2B cells. Toxicology Letters, 180, 222-229.

Portakal, O., 2008. Bioassays and nanoparticles. Turkish Journal of Biochemistry 33: 35-38.

Schmidt V, Wittemann JV, Senz S, Gosele U (2009) Silicon nanowires: a review on aspects of their growth and their electrical properties. Advanced Materials, 29, 2681- 2702.

Şekeroğlu-Atlı, Z., 2013. From nanotechnology to nanogenotoxicology: genotoxic effect of cobaltchromium nanoparticles. Turkish Bulletin of Hygiene and Experimental Biology, 70, 33-42.

Sonmez, E., Turkez, H., Aydın, E., Özgeriş, F.B., Öztetik, E. and Kerli, S., 2015. Hepatic effects of yttrium oxide nanoflowers: in vitro risk evaluation. Toxicological \& Environmental Chemistry, 97, 599-608.

Stampoulis, D., Sinha, S.K. and White, J.C., 2009. Assay-dependent phytotoxicity of nanoparticles to plants. Environmental Science \& Technology, 43, 94739479.

Syed, S., Zubair, A. and Frieri, M., 2013. Immune response to nanomaterials: implications for medicine and literature review. Current Allergy and Asthma Reports, 13, 50-57.

The Royal Society and The Royal Academy of Engineering. Nanoscience and nanotechnologies: opportunities and uncertainties, 2004, London, UK.

Tomalia, D.A., Reyna, L.A. and Svenson, S., 2007. Dendrimers as multipurpose nanodevices for oncology drug delivery and diagnostic imaging. Biochemical Society Transactions, 35, 61-67.

Turkez, H., Sonmez, E., Aydin, E., Hacımuftuoglu, A. and Öztetik, E., 2016. Choosing the right antioxidant supplement for protecting liver from toxicity of engineered nanoparticles: a comprehensive 
invitroscreening. Applied Mechanics and Materials, 835, 57-62.

Ünlü, S. and Sağlar, E., 2012. Investigation of MDM2 gene expression changes in peripheral blood lymphocytes after in-vitro gamma radiation exposure. Firat University Medical Journal of Health Sciences, 26, 87-90.

Yang, H., Liu, C., Yang, D., Zhang, H. and Xi, Z., 2009. Comparative study of cytotoxicity, oxidative stress and genotoxicity induced by four typical nanomaterials: the role of particle size, shape and composition. Journal of Applied Toxicology, 29, 69-78.

Yokogawa, K., Watanabe, M., Takeshita, H., Nomura, M., Mano, Y. and Miyamoto, K., 2004. Serum aminotransferase activity as a predictor of clearance of drugs metabolized by CYP isoforms in rats with acute hepatic failure induced by carbon tetrachloride. International Journal of Pharmaceutics, 269, 479-489.

Yolanda, P., 2016. Challenges in the determination of engineered nanomaterials in foods. Trends in Analytical Chemistry, 84, 149-159.

Zhang, W.X. and Elliott, D.W., 2006. Applications of iron nanoparticles for ground water remediation. Remediation, 16, 7-21.

Ziady, A.G., Gedeon, C.R., Muhammad, O., Stillwell, V., Oette, S.M., Fink, T.L., Quan, W., Kowalczyk, T.H., Hyatt, S.L., Payne, J., Peischl, A., Seng, J.E., Moen, R.C., Cooper, M.J. and Davis, P.B., 2003. Minimal toxicity of stabilized compacted DNA nanoparticles in the murine lung. Molecular Therapy, 8, 948- 956.

Zschech, D., Kim, D.H., Milenin, A.P., Scholz, R., Hillebrand, R., Hawker, C.J., Russell, T.P., Steinhart, M. and Gösele, U., 2007. Ordered arrays of $\langle 100\rangle$ oriented silicon nanorods by cmos-compatible block copolymer lithography. Nano Letters, 7, 1516- 
